Article

\title{
Analysis of Different Solution Treatments in the Transformation of $\beta$-AlFeSi Particles into $\alpha$-(FeMn)Si and Their Influence on Different Ageing Treatments in Al-Mg-Si Alloys
}

\author{
Florentino Alvarez-Antolin * ${ }^{\mathbb{C}}$, Juan Asensio-Lozano ${ }^{\circledR}$, Alberto Cofiño-Villar \\ and Alejandro Gonzalez-Pociño \\ Materials Pro Group, Department of Materials Science and Metallurgical Engineering, University of Oviedo, \\ Independencia 13, 33004 Oviedo, Spain; jasensio@uniovi.es (J.A.-L.); UO229780@uniovi.es (A.C.-V.); \\ gonzalezpalejandro@uniovi.es (A.G.-P.) \\ * Correspondence: alvarezflorentino@uniovi.es; Tel.: +34-985181949
}

Received: 7 April 2020; Accepted: 7 May 2020; Published: 10 May 2020

check for updates

\begin{abstract}
In the as-cast state, $\mathrm{Al}-\mathrm{Mg}-\mathrm{Si}$ alloys are not suitable for hot forming. They present low ductility due to the presence of intermetallic $\beta$-AlFeSi particles that form in the interdendritic regions during the solidification process. Homogenization treatments promote the transformation of these particles into $\alpha-(\mathrm{FeMn}) \mathrm{Si}$ particles, which are smaller in size and more rounded in shape, thus improving the ductility of the material. This paper analyses the influence of various solution treatments on the transformation of $\beta$-AlFeSi particles into $\alpha$-(FeMn)Si particles in an Al 6063 alloy. Their effect on different ageing treatments in the $150-180{ }^{\circ} \mathrm{C}$ temperature range is also studied. An increase in the solution temperature favours greater transformation of the $\beta$-AlFeSi particles into $\alpha$-(FeMn)Si, dissolving a greater amount of $\mathrm{Si}$, thereby having a significant effect on subsequent ageing. We found that as the dwell time at a temperature of $600{ }^{\circ} \mathrm{C}$ increases, the rate of dissolution of the Fe atoms from $\alpha$-(FeMn)Si particles exceeds the rate of incorporation of $\mathrm{Mn}$ atoms into said particles. This seems to produce a delay in reaching the peak hardness values in ageing treatments, which warrants further research to model this behaviour. The optimal solution treatment takes place at around $600^{\circ} \mathrm{C}$ and the highest obtained peak hardness value is $104 \mathrm{HV}$ after a $2 \mathrm{~h}$ solution treatment at said temperature and ageing at $160^{\circ} \mathrm{C}$ for $12 \mathrm{~h}$.
\end{abstract}

Keywords: $\mathrm{Al}-\mathrm{Mg}-\mathrm{Si} ; \alpha-\mathrm{Al}_{8}\left(\mathrm{Fe}_{2} \mathrm{Mn}\right) \mathrm{Si}$ particles; solution treatment; ageing; dissolution of $\mathrm{Fe}$; Differential Scanning Calorimetry

\section{Introduction}

Aluminium alloys usually have iron as a common impurity. The maximum equilibrium solubility of Fe in solid aluminium is very low. Thus, most Fe forms Fe-rich intermetallic compounds together with other elements, which appear as needles or sharp edges in the microstructure. Some types of Fe-rich intermetallic compounds are very harmful to mechanical properties, especially ductility [1]. The particles present in Al-Mg-Si alloys during solidification are mostly $\beta$-AlFeSi (generally the $\beta-\mathrm{Al}_{5} \mathrm{FeSi}$ phase), $\alpha$-AlFeSi (generally the $\alpha-\mathrm{Al}_{8} \mathrm{Fe}_{2} \mathrm{Si}$ phase) and $\mathrm{Mg}_{2} \mathrm{Si}$ [1-3]. These alloys are not suitable for hot forming processes in the as-cast state or in processes of intensive deformation, as occurs in extrusion. Their ductility is too low, mainly due to the presence of intermetallic $\beta$-AlFeSi particles that locate at interdendritic regions, giving rise to the occurrence both inside the $\alpha$-Al grains and at their grain boundaries after solidification is completed [4]. These particles usually have an acicular morphology in the polished plane. Hot ductility is impaired by the presence of these 
particles, decreasing significantly as their content increases. The purpose of the high-temperature homogenization process is the chemical homogenization of the dendrites, as well as the simultaneous fragmentation of the $\beta-\mathrm{Al}_{5} \mathrm{FeSi}$ precipitates, thus avoiding their continuity along the grain boundaries and favouring their conversion into $\alpha-\mathrm{Al}(\mathrm{FeMn}) \mathrm{Si}$ particles with rounded edges, which increase ductile behaviour. This conversion must be complete in hot extrusion processes, as they take place in a single stage with intensive deformation and in a very short time. Hot rolling processes that obtain flat rolled products and multi-pass hot strip mills enable the decrease in temperatures and homogenization times without completing the total transformation of $\beta$ particles into $\alpha$ particles. $\beta$-AlFeSi particles can lead to local crack initiation and induce surface defects on the extruded material. The more rounded $\alpha-\mathrm{Al}(\mathrm{FeMn}) \mathrm{Si}$ particles in the homogenized material improve the extrudability of the material as well as the surface quality of the extruded material [5]. The morphology of the Fe-rich phase is related to many factors, such as the composition of the alloy, the cooling rate, and the content of Fe. During solidification, for example, $\alpha-\mathrm{Al}_{8} \mathrm{Fe}_{2} \mathrm{Si}$ tends to form at higher cooling rates than $\beta-\mathrm{Al}_{5} \mathrm{FeSi}[6]$. The presence of $\mathrm{Mn}$ can change the morphology of the acicular Fe-rich phase and form a granular intermetallic $\alpha-\mathrm{Al}(\mathrm{MnFe}) \mathrm{Si}$ phase $[7,8]$. The formation of the $\beta$-AlFeSi particles is prior to, or at least concurrent with, the solidification of the alloy, which is why these precipitates are found in the interdendritic regions. The same grain can eventually encompass several dendrites. Therefore, these particles can appear inside the grains. As a result, the above processes lead to an increase in hot ductility [9]. A homogenization heat treatment promotes the transformation of these needle-like particles into smaller particles with more rounded shapes denoted as $\alpha-(\mathrm{FeMn}) \mathrm{Si}, \alpha-\mathrm{Al}_{8}(\mathrm{FeMn})_{2} \mathrm{Si}$ or $\alpha-\mathrm{Al}_{12}(\mathrm{FeMn})_{3} \mathrm{Si}$ [5], which allows an enhancement in the ductility of the material [9-14]. The main force inducing the transformation of the $\beta$ particles into $\alpha$ particles is found in the difference of Fe concentration between the $\mathrm{Al}$ matrix and the $\beta$ particles themselves. It has been found that an Fe content in the alloy between $0.15 \%$ and $0.25 \%$ favours the appearance of smaller volume fractions of $\beta$ intermetallics during solidification and promotes fine acicular morphologies, favouring a faster $\beta \rightarrow \alpha$ transformation [15]. Moreover, the Mn in turn modifies this inducing force by causing variations in the concentration of Fe in the matrix and $\beta$ interfaces. Kuijpers et al. determined that the optimal rate of transformation of $\beta$ particles into $\alpha$ particles occurs when the manganese concentration falls within the $0.02 \%$ to $0.2 \%$ range [16]. With an increase in solution time, the acicular morphology of the $\beta$-AlFeSi particles can be transformed into rounded shapes and the $\alpha-\mathrm{Al} 8(\mathrm{FeMn})_{2} \mathrm{Si}$ phase can be formed. A minimal amount of Mn is needed to promote this transformation. The desirable $\mathrm{Mn} / \mathrm{Fe}$ ratio could be around 0.5 . The $\alpha-(\mathrm{FeMn}) \mathrm{Si}$ particles present an Fe/Si atomic ratio that is higher than that of its homologous $\beta$ phase. Therefore, the solid solution of $\mathrm{Si}$ in the matrix phase accordingly increases, favouring subsequent hardening via an ageing treatment $[12,17]$. Lui et al. concluded that the $(\mathrm{Fe}+\mathrm{Mn}) / \mathrm{Si}$ atomic ratio remains constant in homogenization treatments within the $550-580{ }^{\circ} \mathrm{C}$ temperature range [18]. In addition to the aforementioned objectives, the homogenization treatment also aims to reduce the microsegregation produced during non-equilibrium solidification and endow the material with a fine, homogeneous structure of precipitates that ensures its subsequent manufacture. The final mechanical properties are determined by the solution heat treatment, quench rate and ageing heat treatment employed. In the solution heat treatment, the aim is to dissolve the phases containing $\mathrm{Mg}$ and Si. The temperatures employed in these alloys usually fall within the $460-530{ }^{\circ} \mathrm{C}$ range [19]. Chen et al. placed the optimal treatment at $520^{\circ} \mathrm{C}$ for $3.5 \mathrm{~h}$ [20]. The ageing of these alloys begins with the formation of clusters in the Guinier-Preston (GP) zones followed by sequential precipitation of the $\beta$ " phase and other metastable phases until precipitation of the $\beta$ equilibrium phase is achieved [21]. The high level of saturation and high concentration of voids that the $\alpha-\mathrm{Al}$ phase presents after quenching promotes the rapid formation of Si clusters and/or GP zones. These clusters have a high concentration of solute and maintain absolute coherence with the matrix, although elastic stresses are induced around them due to the difference in size between the atoms of the solute and those of the solvent. At this point, there is an increase in hardness, as these clusters/zones constitute a major obstacle to the displacement of dislocations [22,23]. Transition precipitates that are coherent with the matrix may nucleate from these 
zones. The increase in strength is defined by the size of the precipitates, their distribution, and their coherence with the matrix. In these alloys, the precipitate responsible for hardening is the $\beta^{\prime \prime}$ (associated with the $\mathrm{Mg}_{2} \mathrm{Si}$ phase) [22-25]. It was found that the width of the precipitate-free zones (PFZs) was significant and optimal precipitation was associated with low thickness [26,27]. The temperatures used in the solubilization treatment and the dwell times at these temperatures seem to have a significant influence on the strength obtained after the ageing treatment. An increase in the temperature or dwell times at the aforementioned temperatures seems to favour an increase in strength after ageing [19,28]. Nandy et al. managed to obtain a peak hardness value of $90 \mathrm{HV}$ by ageing at $175^{\circ} \mathrm{C}$ for around $8 \mathrm{~h}$, after a solution treatment at $525^{\circ} \mathrm{C}$ for $2 \mathrm{~h}$ [29]. Yuksel obtained a maximum hardness value of nearly $100 \mathrm{HV}$ by means of a solution treatment at $535^{\circ} \mathrm{C}$ for $2 \mathrm{~h}$ and ageing at $204{ }^{\circ} \mathrm{C}$ for $2 \mathrm{~h}$ [25]. Note that the greatest decrease in hardness due to over-ageing was obtained at this same temperature compared to lower ageing temperatures. Several authors concluded that the rate of cooling prior to ageing and after the solubilization treatment seems to influence the peak hardness value after the ageing treatment. This cooling rate should be as high as possible in order to achieve the maximum supersaturation of Si and $\mathrm{Mg}$ in solid solution [24,30-32]. The most sensitive temperature range at industrial cooling rates seems to be between 450 and $250{ }^{\circ} \mathrm{C}$ [24,31,33]. Prolonged solubilization treatments are necessary in order to ensure the total dissolution of the $\mathrm{Mg}_{2} \mathrm{Si}$ formed in the cooling after chemical homogenization. As a form of validation, it is likewise necessary to employ a cooling rate which is fast enough to avoid the premature precipitation of $\mathrm{Mg}_{2} \mathrm{Si}$. This would allow the full potential of structural hardening to be available in the subsequent ageing process.

The aim of this paper is to analyse the influence of various solution treatments, employing quenching in water, on the transformation of the $\beta$-AlFeSi particles in an Al 6063 alloy into $\alpha$-(FeMn)Si particles and their possible influence on different ageing treatments carried out in the $150-180{ }^{\circ} \mathrm{C}$ range.

\section{Materials and Methods}

One hundred twenty specimens were taken from the intermediate zone of the radius of a number of 200-mm-diameter slabs in the as-cast state. Table 1 shows the chemical composition of the as-cast material. These slabs were manufactured by continuous casting in discontinuous processes, with cooling and lubrication by demineralized water in the die. The round aluminium products had an approximate diameter of $228 \mathrm{~mm}$ and a length of $12 \mathrm{~m}$. The cooling rates measured at the centre of these products were $1 \mathrm{~K} / \mathrm{s}$, and $20 \mathrm{~K} / \mathrm{s}$ at the surface. The specimens had a cubic geometry measuring 12-15 mm per side. One hundred sixteen of these specimens were subjected to four solution treatments, employing three different ageing temperatures for each. Quenching in water at $15{ }^{\circ} \mathrm{C}$ was used after the solution treatments. Figure 1 outlines the experimental work carried out. The 120 specimens were distributed as follows:

(1) 108 specimens were used to obtain the hardness profiles: 4 different solution treatments were carried out, employing 3 ageing treatments per solution treatment, with a total of 9 specimens in each ageing treatment.

(2) 8 specimens had no ageing. There were 2 specimens after each solution treatment, one was used for metallographic inspection and calculation of the material's hardness, while the other was used for differential scanning calorimetry (DSC).

(3) The remaining 4 specimens were analysed in the as-cast state.

Table 1. Chemical composition (\% by weight).

\begin{tabular}{cccccc}
\hline$\% \mathbf{S i}$ & $\% \mathrm{Fe}$ & $\% \mathbf{C u}$ & $\% \mathbf{M g}$ & $\% \mathbf{M n}$ & $\% \mathbf{T i}$ \\
\hline 0.42 & 0.22 & 0.018 & 0.47 & 0.031 & 0.019 \\
\hline
\end{tabular}

Metallographic inspection was carried out using an optical microscope and a scanning electron microscope. 
Preparation of the metallographic specimens was carried out by cutting with a $\mathrm{SiC}$ disc, cold mounting with an epoxy resin, grinding with $\mathrm{SiC}$ paper of different abrasive grain sizes ranging from grit 240 to 600 then finally polishing in three steps with textile cloths using different types of abrasives in each step. In the first step, 6 and $1 \mu \mathrm{m}$ diamond paste was used, while a $0.5 \mu \mathrm{m}$ alumina solution in distilled water was used in the second step. In the third stage, a $0.05 \mu \mathrm{m}$ colloidal silica solution, which was also in distilled water, was utilized.

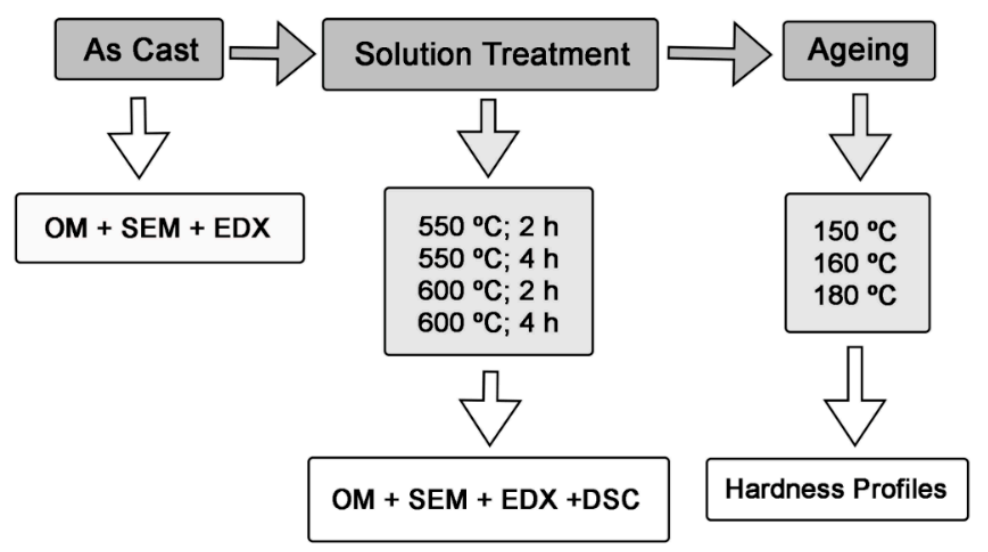

Figure 1. Outline of the experimental work carried out. OM: optical microscopy; DSC: differential scanning calorimetry; EDX: energy dispersive X-ray spectroscopy; SEM: scanning electron microscopy.

The etching reagents used in the optical microscopy analysis were:

(1) $2 \mathrm{~mL} \mathrm{HF}, 3 \mathrm{~mL} \mathrm{HCl}, 5 \mathrm{~mL} \mathrm{HNO}_{3}$ and $190 \mathrm{~mL}$ distilled water.

(2) A solution made of $4 \mathrm{~g} \mathrm{KMnO}_{4}, 1 \mathrm{~g} \mathrm{NaOH}$ and $100 \mathrm{~mL}$ distilled water. This reagent reveals the chemical heterogeneities derived from dendritic microsegregation.

The optical microscope used was a NIKON Epiphot 200 (Nikon, Tokyo, Japan) and the images were obtained using Beuhler Omnimet Enterprise image analyser software (5.0, Beuhler, Lake Bluff, USA). The scanning electron microscope employed was a JEOL JSM-5600 (JEOL, Nieuw-Vennep, The Netherlands). The $\mathrm{Fe} / \mathrm{Si}$ atomic ratio in the $\alpha-\mathrm{Al}(\mathrm{FeMn}) \mathrm{Si}$ particles was determined on metallographic samples in the polished state, without etching with a chemical reagent. Energy dispersive X-ray (EDX) microanalysis was used for this purpose, randomly analysing 30 particles per specimen $(20 \mathrm{kV}$ with reflections of up to $10 \mathrm{keV}$ ).

Vickers hardness values were obtained under the application of a $300 \mathrm{~N}$ load. The results correspond to the mean value obtained from 12 indentations per specimen.

The differential scanning calorimeter used was a Mettler Toledo DSC 822e (Metter Toledo, Schwerzenbach, Switzerland). The heating rate was $10^{\circ} \mathrm{C} / \mathrm{min}$, and the test was conducted between 25 and $500{ }^{\circ} \mathrm{C}$. The results obtained by DSC will not provide us with the isothermal temperature at which the precipitation of the metastable phases that cause structural hardening takes place. During the DSC test, these temperatures are obtained by means of a heating ramp and are therefore always higher than the temperatures used isothermally for artificial ageing. However, when the aim is to compare various ageing treatments, this test allows us to compare whether said precipitation of structural hardening will occur sooner or later.

\section{Results}

Figure 2 shows the microstructure obtained in the as-cast state. It can be seen that the microstructure presents dendritic segregation and precipitation of $\beta-\mathrm{Al}_{5} \mathrm{FeSi}$ particles in the segregated zones, preferably at the grain boundaries. Figure 3 shows images of this microstructure obtained using electron channelling contrast imaging (ECCI) [34]. The elongated, acicular morphology of the $\beta-\mathrm{Al}_{5} \mathrm{FeSi}$ 
particles can be observed, forming a more or less continuous network through the grain boundaries network of the $\alpha-\mathrm{Al}$ phase. It can also be seen that the grain size is around $200-250 \mu \mathrm{m}$. Figure 4 shows the microstructure obtained following the solution treatments with cooling in water. A homogenized microstructure can be seen in all cases, with no dendritic segregation. A decrease in the volume fraction of AlFeSi particles and loss of their continuity were likewise observed. Figure 5 shows the transformation of the microstructure during the homogenization treatment. Figure 5a shows the microstructure obtained in the as-cast state. The $\beta-\mathrm{Al}_{5} \mathrm{FeSi}$ particles and the $\mathrm{Mg}_{2} \mathrm{Si}$ phase can be observed, both located at a grain boundary. Figure $5 \mathrm{~b}$ shows the microstructure after solubilization at $600{ }^{\circ} \mathrm{C}$, employing cooling in water. This treatment also allows the solubilization of the $\mathrm{Mg}_{2} \mathrm{Si}$ phase and the transformation of the $\beta-\mathrm{Al}_{5} \mathrm{FeSi}$ particles into $\alpha-\mathrm{Al}_{8}(\mathrm{FeMn})_{2} \mathrm{Si}$ particles. Cooling in water prevented solid-state precipitation of $\mathrm{Mg}_{2} \mathrm{Si}$.

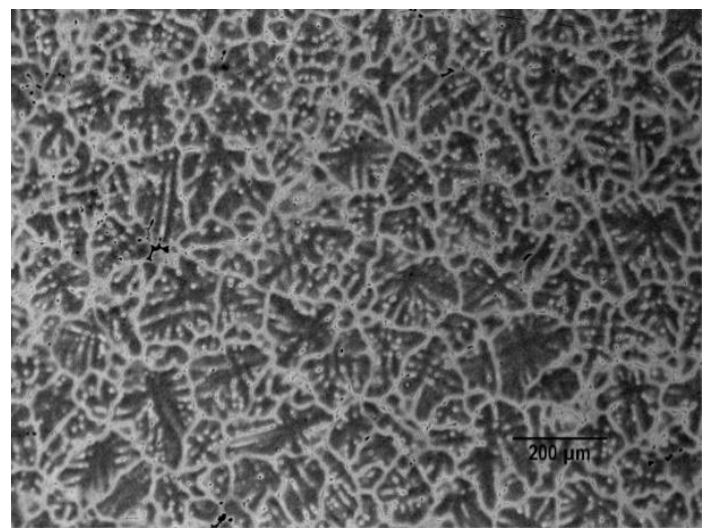

(a)

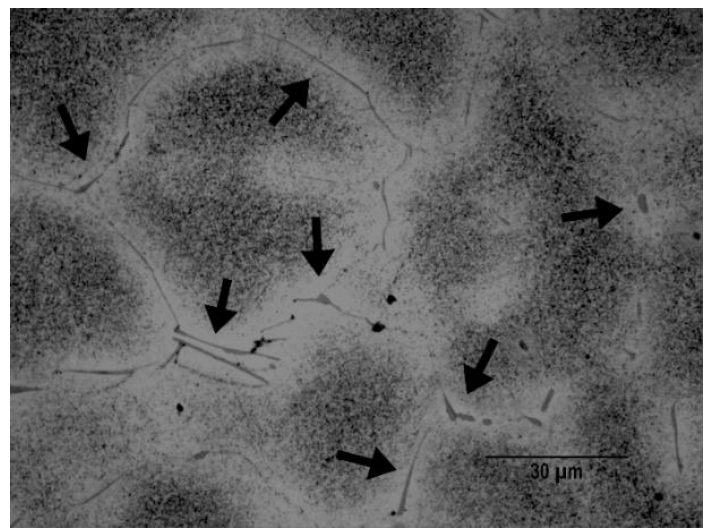

(b)

Figure 2. Microstructure in the as-cast state. (a) Dendritic segregation is observed; (b) $\beta-\mathrm{Al}_{5} \mathrm{FeSi}$ particles at the grain boundaries. The etching reagent consisted of a solution of $100 \mathrm{~mL}$ distilled water with $4 \mathrm{~g} \mathrm{KMnO}_{4}$ and $1 \mathrm{~g} \mathrm{NaOH}$.

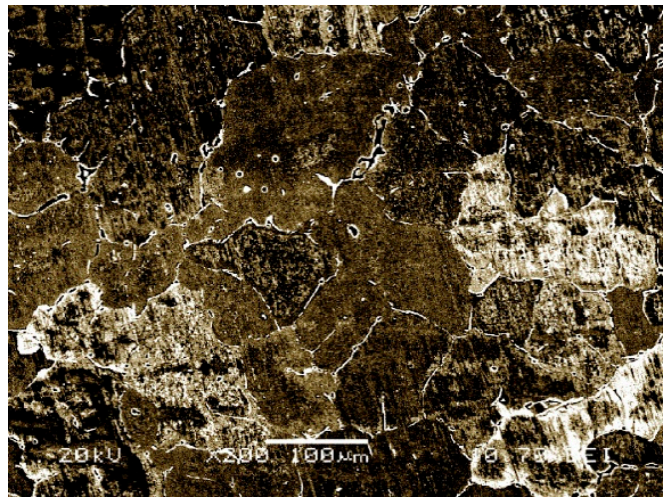

(a)

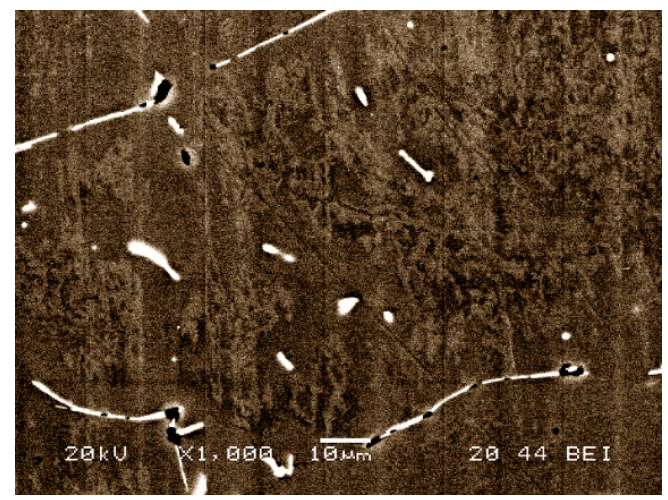

(b)

Figure 3. Microstructure in the as-cast state obtained under a scanning electron microscope (SEM) using electron channelling contrast imaging (ECCI). (a) It can be seen that the grain size can be estimated to be around $200-250 \mu \mathrm{m}$. (b) The $\beta-\mathrm{Al}_{5} \mathrm{FeSi}$ particles are in white and $\mathrm{Mg}_{2} \mathrm{Si}$ particles are in black. 


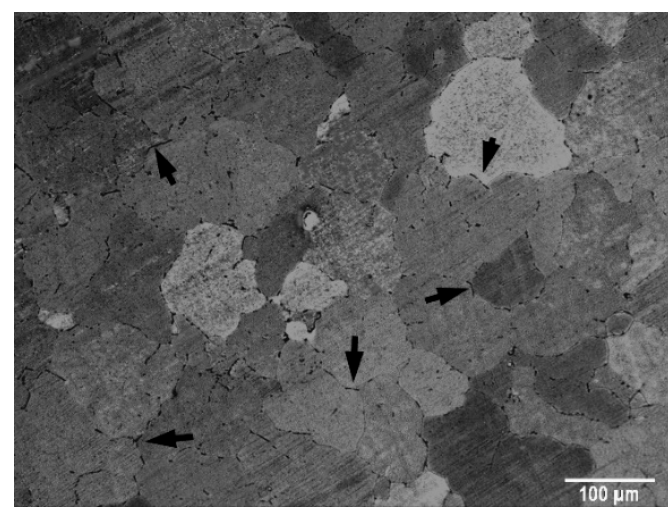

(a)

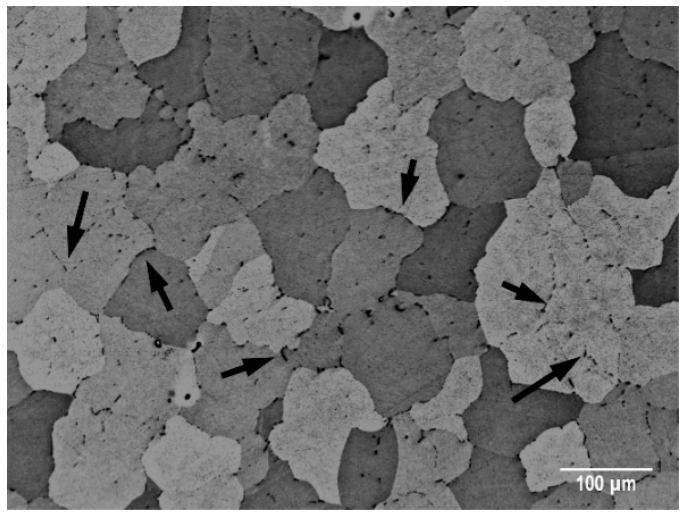

(c)

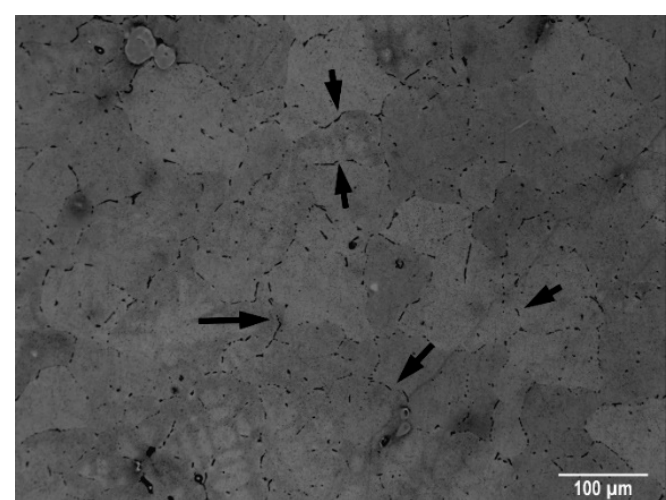

(b)

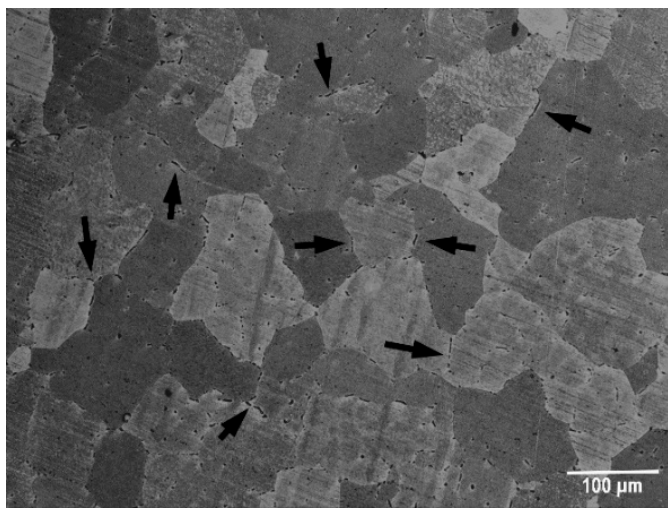

(d)

Figure 4. Microstructure after solution treatments, employing quenching in water. (a) Treatment at $550{ }^{\circ} \mathrm{C}$ for $2 \mathrm{~h}$. (b) Treatment at $550{ }^{\circ} \mathrm{C}$ for $4 \mathrm{~h}$. (c) Treatment at $600{ }^{\circ} \mathrm{C}$ for $2 \mathrm{~h}$. (d) Treatment at $600{ }^{\circ} \mathrm{C}$ for $4 \mathrm{~h}$.

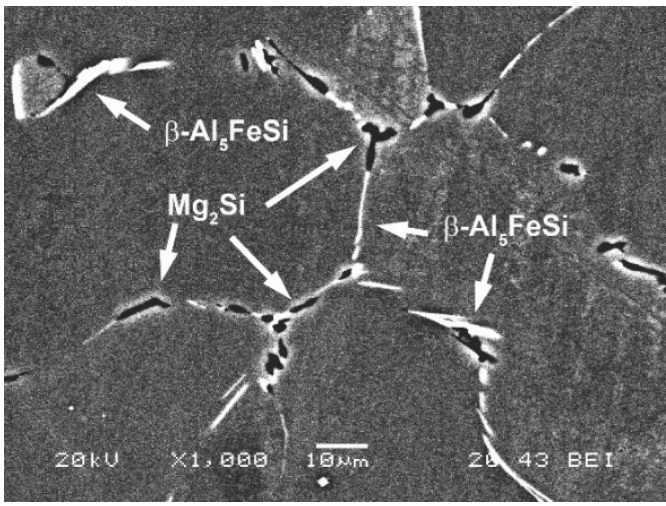

(a)

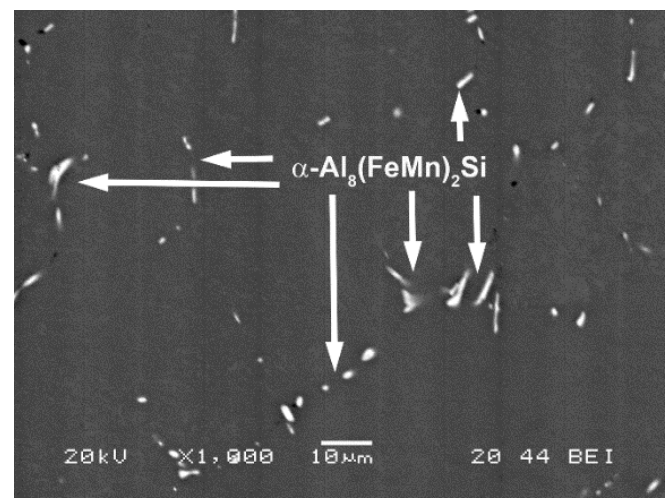

(b)

Figure 5. Microstructures obtained by scanning electron microscopy (SEM). (a) The as-cast state. The $\beta-\mathrm{Al}_{5} \mathrm{FeSi}$ particles and the $\mathrm{Mg}_{2}$ Si phase can be observed, located at a grain boundary. (b) After a solubilization treatment at $600{ }^{\circ} \mathrm{C}$ with water cooling, which enabled the maximum solubilization of the $\mathrm{Mg}_{2} \mathrm{Si}$ phase and the transformation of the $\beta-\mathrm{Al}_{5} \mathrm{FeSi}$ particles into $\alpha-\mathrm{Al}_{8}(\mathrm{FeMn})_{2} \mathrm{Si}$ particles.

Figure 6 shows the $\mathrm{Fe} / \mathrm{Si}$ atomic ratio and the atomic percentage of $\mathrm{Mn}$ in the $\alpha-\mathrm{Al}(\mathrm{FeMn}) \mathrm{Si}$ particles, while Figure 7 shows the $(\mathrm{Fe}+\mathrm{Mn}) / \mathrm{Si}$ ratio, along with the atomic percentages of $\mathrm{Si}$ and Fe. It can be observed that the Fe/Si ratio was higher in treatments at $600{ }^{\circ} \mathrm{C}$ than in treatments at $550{ }^{\circ} \mathrm{C}$, a finding that could be justified by the greater dissolution of Si atoms at $600{ }^{\circ} \mathrm{C}$. This would allow an increase in the potential for structural hardening. However, this ratio decreased when the 
duration of the treatment was $4 \mathrm{~h}$. Note that the atomic \% of Fe in the $\alpha$ particles was much lower in the treatments at $600^{\circ} \mathrm{C}$, being lower with dwell times of $4 \mathrm{~h}$ versus $2 \mathrm{~h}$. Moreover, the $\beta$-AlFeSi particles in the as-cast state do not contain Mn atoms. However, as the dwell times of the treatment temperature increased, the atomic content of $\mathrm{Mn}$ in the $\alpha-\mathrm{Al}(\mathrm{FeMn}) \mathrm{Si}$ particles also increased.

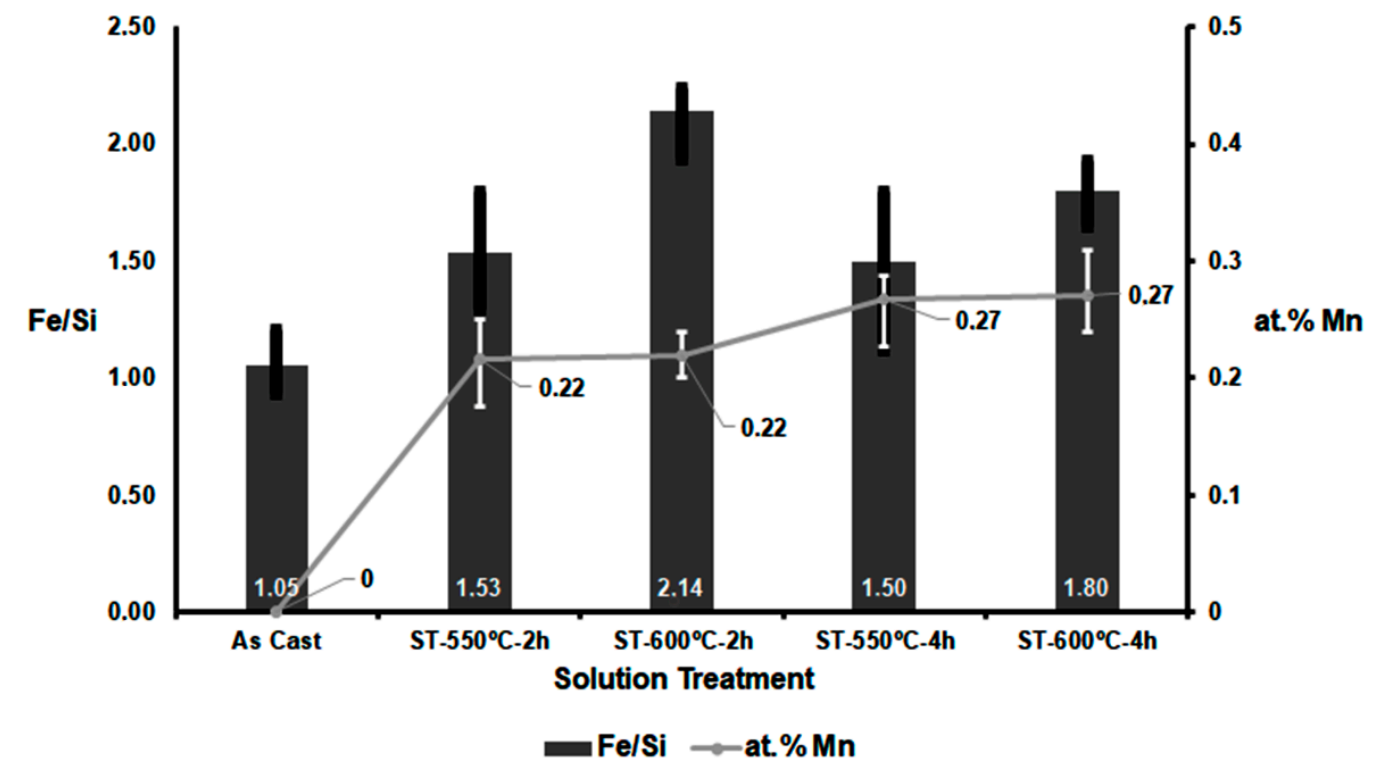

Figure 6. Mean Fe/Si atomic ratio of AlFeSi particles after the different solution treatments (ST). The results are correlated with the atomic \% of Mn in these particles. The "As Cast" state refers to the $\beta-\mathrm{Al}_{5} \mathrm{FeSi}$ particles, while the state after the solution treatment refers to the $\alpha-\mathrm{Al}_{8}(\mathrm{FeMn})_{2} \mathrm{Si}$ particles. The error bars show the distance between the mean value and the maximum and minimum values of the 30 particles analysed in each specimen.

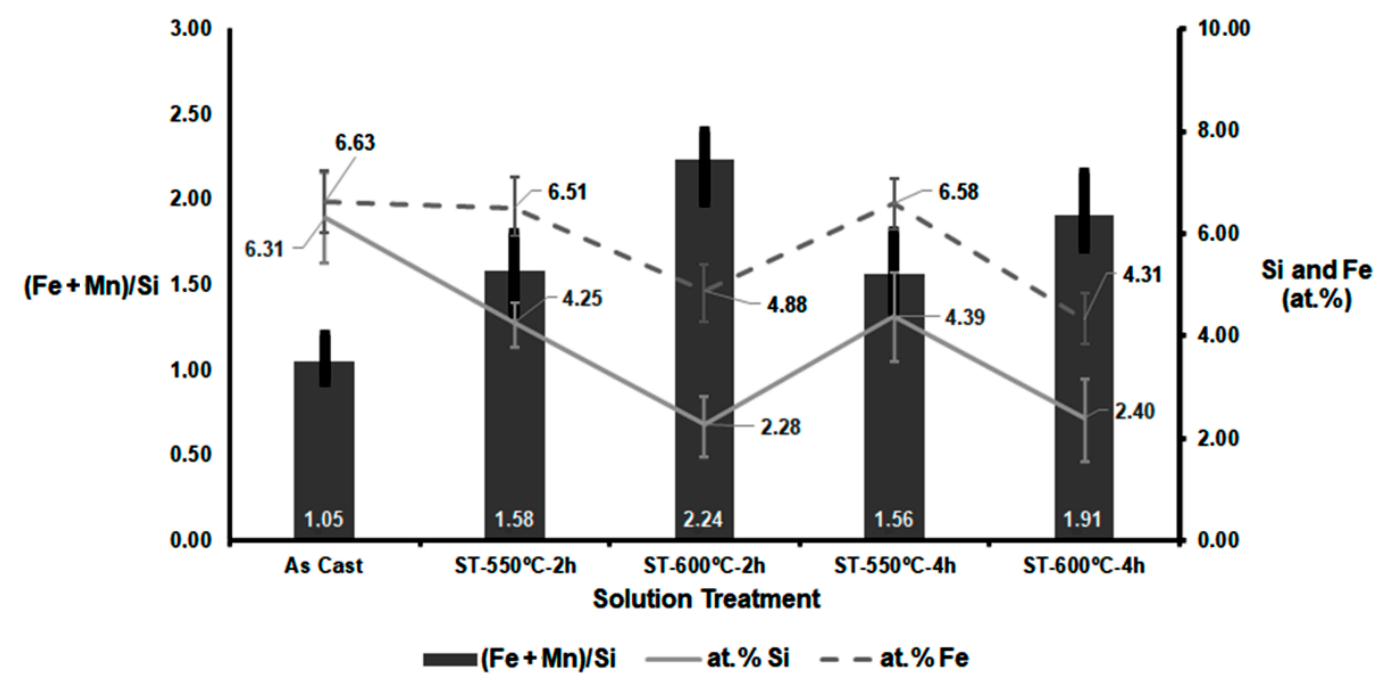

Figure 7. Mean $(\mathrm{Fe}+\mathrm{Mn}) / \mathrm{Si}$ atomic ratio of $\mathrm{AlFeSi}$ particles after the different solution treatments (ST). The atomic percentages of $\mathrm{Si}$ and Fe are also shown. The "As Cast" state refers to $\beta-\mathrm{Al}_{5} \mathrm{FeSi}$ particles, while the state after the solution treatment refers to the $\alpha-\mathrm{Al}_{8}(\mathrm{FeMn})_{2} \mathrm{Si}$ particles. The error bars show the distance between the mean value and the maximum and minimum values of the 30 particles analysed in each specimen. 
The hardness value in the as-cast state was $40 \mathrm{HV}$ and the hardness value obtained after these treatments was $45 \mathrm{HV}$, with no differences in hardness being found between the different solution treatments. The hardness test was carried out immediately after these treatments.

Figure 8 shows the results obtained after the DSC analysis. Two main exothermic peaks were detected, designated as A and C. Peak A corresponds to precipitation of the $\beta^{\prime \prime}$ and $\beta^{\prime}$ phases. In between peaks $A$ and $C$ is the endothermic peak $B$ that corresponds to the dissolution of these phases. Lastly, peak $C$ corresponds to the precipitation of the $\beta$ phase [35-42]. The endothermic peak prior to the exothermic peak A shows the dissolution of the GP zones formed during natural ageing. The results of the DSC test provide the temperatures at which the structural hardening precipitations are verifiable when this temperature is reached by means of a heating ramp. In our case, the heating rate is $10^{\circ} \mathrm{C} / \mathrm{min}$. This means that these temperatures cannot be compared with the isothermal ageing temperatures, the latter being necessarily lower. However, when the aim is to compare various ageing treatments, this test allows us to compare whether the structural hardening will occur sooner or later. The solution treatment at $600{ }^{\circ} \mathrm{C}$ with a dwell time of $4 \mathrm{~h}$ produced the greatest delay in the formation of the metastable transition phases (Peak A) and their subsequent dissolution (Peak B). This delay could be related to the dissolution of the Fe atoms that were observed in the previous solution treatment at this temperature with prolonged dwell times, which could be grounds for further investigation in this regard.

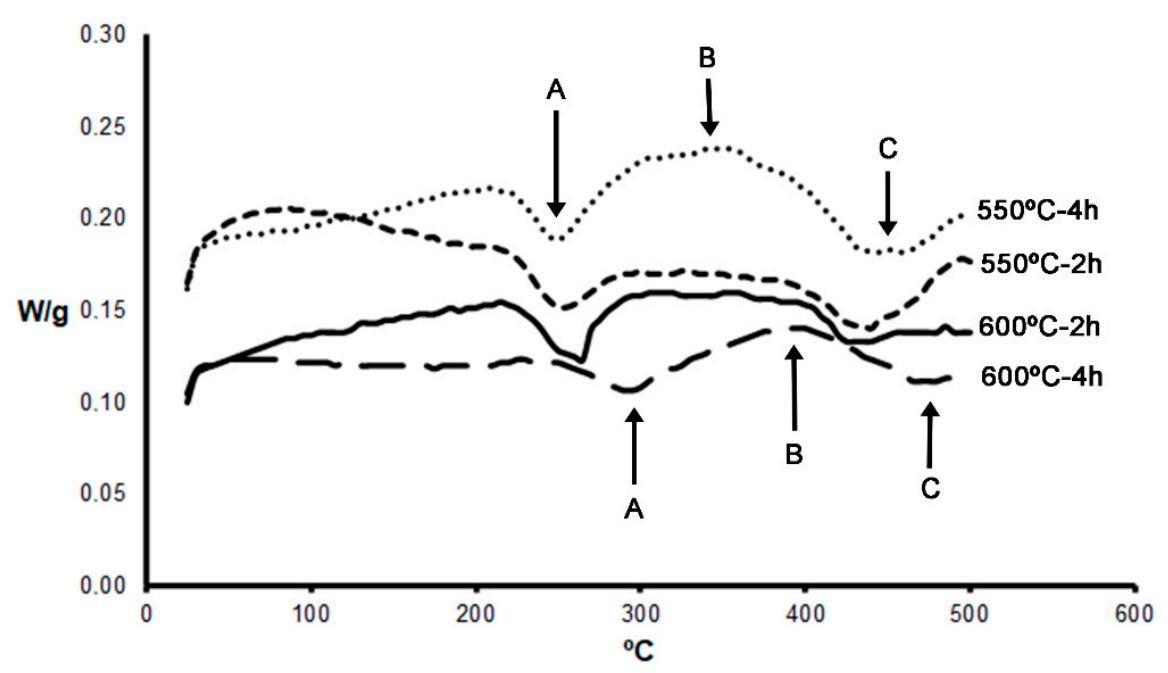

Figure 8. Continuous heating DSC at $10{ }^{\circ} \mathrm{C} / \mathrm{min}$. The samples were previously aged naturally. The exothermic peaks (A and $C$ ) indicate precipitation of the $\beta^{\prime \prime}-\beta^{\prime}$ and $\beta$ phases, respectively. The endothermic peak (B) reflects the dissolution of the $\beta^{\prime \prime}-\beta^{\prime}$ phases, precipitated in $A$.

Figure 9 shows the hardness profiles obtained after the ageing treatments. The peak hardness values were obtained with solution treatments at $600{ }^{\circ} \mathrm{C}$, which are the ones that dissolved the highest $\%$ Si from the $\beta$-AlFeSi particles. This would allow more Si to be available in solid solution for the subsequent precipitation of the metastable $\beta$ " phase during ageing. The peak hardness value was $104 \mathrm{HV}$ after the solution treatment at $600{ }^{\circ} \mathrm{C}$ for $2 \mathrm{~h}$ and ageing at $160{ }^{\circ} \mathrm{C}$ for $12 \mathrm{~h}$. Very similar hardness profiles following the solution treatment at $550{ }^{\circ} \mathrm{C}$ were obtained with dwell times of 2 and $4 \mathrm{~h}$. However, the peak hardness values obtained after a dwell time of $4 \mathrm{~h}$ at $600{ }^{\circ} \mathrm{C}$ were delayed in the three ageing temperatures compared to the $2 \mathrm{~h}$ dwell time. This fact may be conditioned by the dissolution of Fe atoms observed after the $4 \mathrm{~h}$ dwell time at $600{ }^{\circ} \mathrm{C}$. 


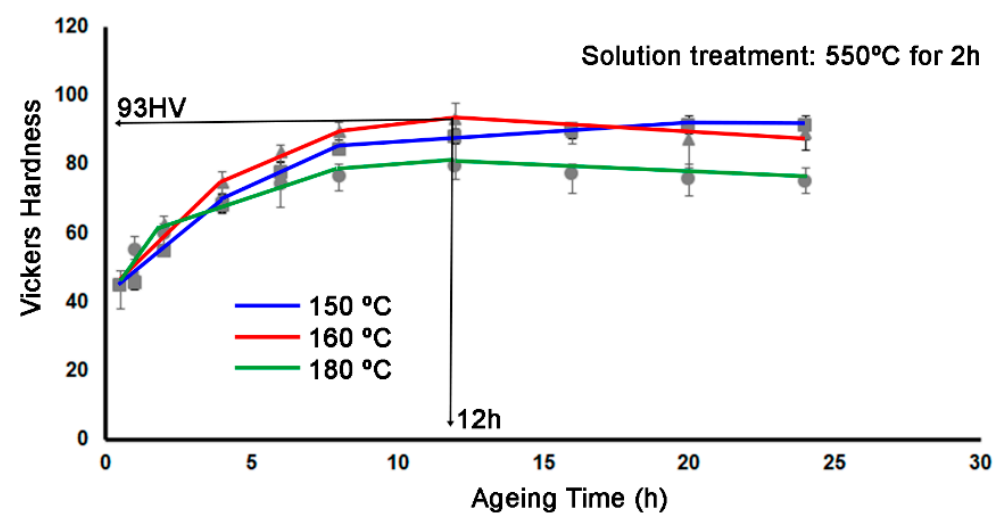

(a)

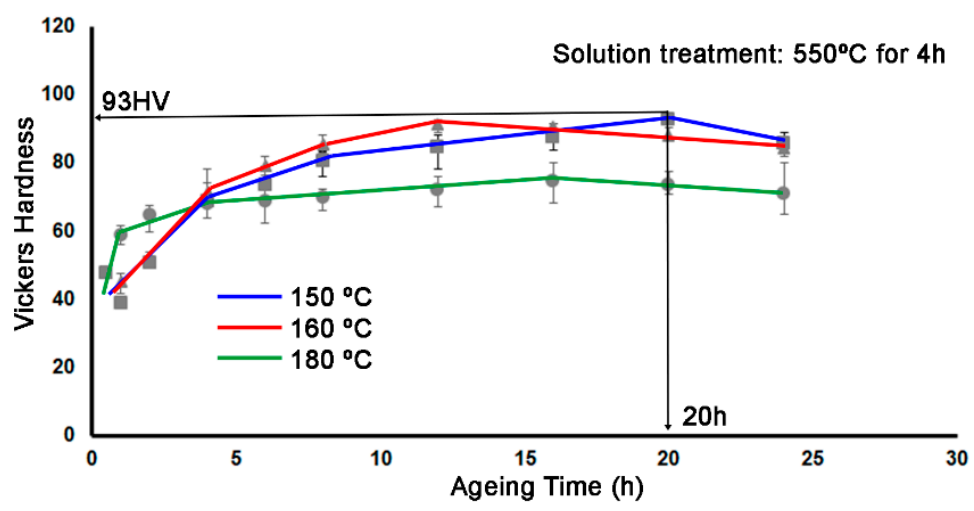

(b)

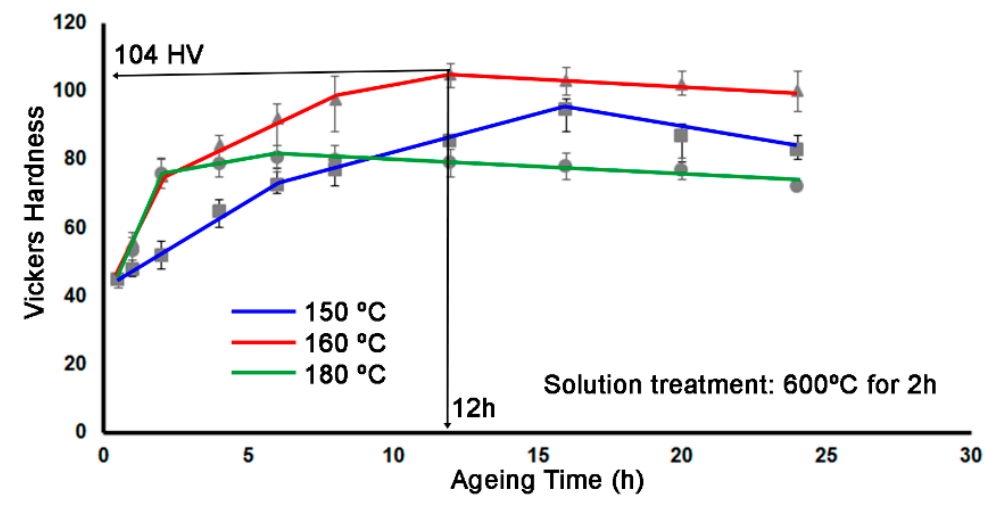

(c)

Figure 9. Cont. 


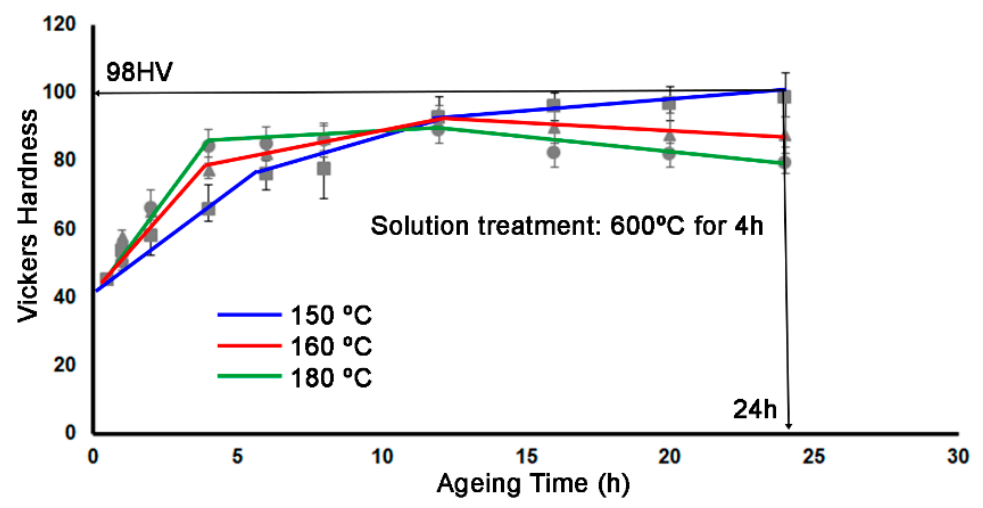

(d)

Figure 9. Hardness profiles after the ageing treatments. (a) Treatment at $550{ }^{\circ} \mathrm{C}$ for $2 \mathrm{~h}$. (b) Treatment at $550{ }^{\circ} \mathrm{C}$ for $4 \mathrm{~h}$. (b) Treatment at $600{ }^{\circ} \mathrm{C}$ for $2 \mathrm{~h}$. (d) Treatment at $600{ }^{\circ} \mathrm{C}$ for $4 \mathrm{~h}$.

\section{Conclusions}

This paper analyses the influence of solution treatments on the transformation of $\beta$-AlFeSi particles into $\alpha$-(FeMn)Si particles and their possible influence on different ageing treatments carried out in the $150-180{ }^{\circ} \mathrm{C}$ range. The main conclusions are:

(1) The $\mathrm{Fe} / \mathrm{Si}$ atomic ratio increased with increasing solution treatment temperature from 550 to $600{ }^{\circ} \mathrm{C}$. This reflects a greater degree of transformation of $\beta-\mathrm{Al}_{5} \mathrm{FeSi}$ particles into $\alpha-\mathrm{Al}_{8}(\mathrm{FeMn})_{2} \mathrm{Si}$ particles, and a greater potential for structural hardening.

(2) In the transformation of $\beta-\mathrm{Al}_{5} \mathrm{FeSi}$ particles into $\alpha-\mathrm{Al}_{8}(\mathrm{FeMn})_{2} \mathrm{Si}$, a greater dissolution of both $\mathrm{Si}$ and $\mathrm{Fe}$ atoms was observed in the matrix when the solution treatment was carried out at $600{ }^{\circ} \mathrm{C}$. The dissolution of Fe was somewhat more pronounced when the dwell times were increased from 2 to $4 \mathrm{~h}$.

(3) At a solution temperature of $550^{\circ} \mathrm{C}$, the $(\mathrm{Fe}+\mathrm{Mn}) / \mathrm{Si}$ atomic ratio remained practically constant. However, at $600{ }^{\circ} \mathrm{C}$, this ratio decreased when the dwell time was increased from 2 to $4 \mathrm{~h}$. This suggests that the rate of dissolution of Fe atoms exceeded the rate of incorporation of $\mathrm{Mn}$ atoms. This could lead to a delay in reaching peak hardness values during ageing at temperatures between 150 and $180^{\circ} \mathrm{C}$.

(4) The peak hardness value obtained was $104 \mathrm{HV}$, following a solution treatment at $600{ }^{\circ} \mathrm{C}$ for $2 \mathrm{~h}$ and ageing at $160^{\circ} \mathrm{C}$ for $12 \mathrm{~h}$.

Author Contributions: J.A.-L. conceived and designed the investigation; A.C.-V. and A.G.-P. performed all laboratory work; F.A.-A. led the investigation, analysed the data, and wrote the paper. All authors have read and agreed to the published version of the manuscript.

Funding: This research received no external funding.

Conflicts of Interest: The authors declare no conflicts of interest.

\section{References}

1. Chanyathunyaroj, K.; Patakham, U.; Kou, S.; Limmaneevichitr, C. Microstructural evolution of iron-rich intermetallic compounds in scandium modified Al-7Si-0.3Mg alloys. J. Alloy. Compd. 2017, 692, 865-875. [CrossRef]

2. Hsu, C.; O’Reilly, K.A.Q.; Cantor, B.; Hamerton, R. Non-equilibrium reactions in 6xxx series $\mathrm{Al}$ alloys. Mater. Sci. Eng. A-Struct. Mater. Prop. Microstruct. Process. 2001, 304, 119-124. [CrossRef] 
3. Sha, G.; O'Reilly, K.; Cantor, B.; Worth, J.; Hamerton, R. Growth related metastable phase selection in a 6xxx series wrought $\mathrm{Al}$ alloy. Mater. Sci. Eng. A-Struct. Mater. Prop. Microstruct. Process. 2001, 304, 612-616. [CrossRef]

4. Li, H.; Wang, J.Y.; Jiang, H.T.; Lo, Z.F.; Zhu, Z.F. Characterizations of precipitation behavior of Al-Mg-Si alloys under different heat treatments. China Foundry 2018, 15, 89-96. [CrossRef]

5. Kuijpers, N.C.W.; Vermolen, F.J.; Vuik, K.; van der Zwaag, S. A model of the beta-AlFeSi to alpha-Al(FeMn)Si transformation in Al-Mg-Si alloys. Mater. Trans. 2003, 44, 1448-1456. [CrossRef]

6. Gorny, A.; Manickaraj, J.; Cai, Z.H.; Shankar, S. Evolution of Fe based intermetallic phases in Al-Si hypoeutectic casting alloys: Influence of the Si and Fe concentrations, and solidification rate. J. Alloy. Compd. 2013, 577, 103-124. [CrossRef]

7. Fan, C.; Long, S.Y.; Yang, H.D.; Wang, X.J.; Zhang, J.C. Influence of Ce and Mn addition on alpha-Fe morphology in recycled Al-Si alloy ingots. Int. J. Miner. Metall. Mater. 2013, 20, 890-895. [CrossRef]

8. Wu, X.Y.; Zhang, H.R.; Zhang, F.X.; Ma, Z.; Jia, L.N.; Yang, B.; Tao, T.X.; Zhang, H. Effect of cooling rate and Co content on the formation of Fe-rich intermetallics in hypoeutectic A17Si0.3Mg alloy with $0.5 \% \mathrm{Fe}$. Mater. Charact. 2018, 139, 116-124. [CrossRef]

9. Zajac, S.; Gullman, L.O.; Johansson, A.; Bengtsson, B. Hot ductility of some Al-Mg-Si alloys. Mater. Sci. Forum 1996, 217, 1193-1198. [CrossRef]

10. Bayat, N.; Carlberg, T.; Cieslar, M. In-situ study of phase transformations during homogenization of 6060 and $6063 \mathrm{Al}$ alloys. J. Phys. Chem. Solids 2019, 130, 165-171. [CrossRef]

11. Sirichaivetkul, R.; Wongpinij, T.; Euaruksakul, C.; Limmaneevichitr, C.; Kajornchaiyakul, J. In-situ study of microstructural evolution during thermal treatment of 6063 aluminum alloy. Mater. Lett. 2019, 250, 42-45. [CrossRef]

12. Couto, K.B.S.; Claves, S.R.; Van Geertruyden, W.H.; Misiolek, W.Z.; Goncalves, M. Effects of homogenisation treatment on microstructure and hot ductility of aluminium alloy 6063. Mater. Sci. Technol. 2005, 21, 263-268. [CrossRef]

13. Kumar, S.; Grant, P.S.; O’Reilly, K.A.Q. Evolution of Fe Bearing Intermetallics During DC Casting and Homogenization of an Al-Mg-Si Al Alloy. Metall. Mater. Trans. A-Phys. Metall. Mater. Sci. 2016, 47A, 3000-3014. [CrossRef]

14. Zajac, S.; Hutchinson, B.; Johansson, A.; Gullman, L.O. Microstructure control and extrudability of al-mg-si alloys microalloyed with manganese. Mater. Sci. Technol. 1994, 10, 323-333. [CrossRef]

15. Asensio-Lozano, J.; Suarez-Pena, B. Quantitative analysis and morphological characterization of 6063 alloy. Microestructural and mechanical comparison between periphery and center of semi-continuous casting round billets. Rev. De Metal. 2012, 48, 199-212. [CrossRef]

16. Kuijpers, N.C.W.; Vermolen, F.J.; Vuik, C.; Koenis, P.T.G.; Nilsen, K.E.; van der Zwaag, S. The dependence of the beta-AlFeSi to alpha-Al(FeMn)Si transformation kinetics in Al-Mg-Si alloys on the alloying elements. Mater. Sci. Eng. A-Struct. Mater. Prop. Microstruct. Process. 2005, 394, 9-19. [CrossRef]

17. Osada, Y. EPMA mapping of small particles of alpha-AlFeSi and beta-AlFeSi in AA6063 alloy billets. J. Mater. Sci. 2003, 38, 1457-1464. [CrossRef]

18. Liu, C.L.; Azizi-Alizamini, H.; Parson, N.C.; Poole, W.J.; Du, Q. Microstructure evolution during homogenization of Al-Mg-Si-Mn-Fe alloys: Modelling experimental results. Trans. Nonferrous Met. Soc. China 2017, 27, 747-753. [CrossRef]

19. Gavgali, M.; Totik, Y.; Sadeler, R. The effects of artificial aging on wear properties of AA 6063 alloy. Mater. Lett. 2003, 57, 3713-3721. [CrossRef]

20. Chen, B.; Wu, Y.J.; Zhu, T.; Li, X.Y. The effects of Solid-solution on properties and microstructure of 6063 aluminum alloy. Adv. Mater. Res. 2014, 881-883, 1346-1350. [CrossRef]

21. Lang, P.; Povoden-Karadeniz, E.; Falahati, A.; Kozeschnik, E. Simulation of the effect of composition on the precipitation in 6xxx Al alloys during continuous-heating DSC. J. Alloy. Compd. 2014, 612, 443-449. [CrossRef]

22. Sjolander, E.; Seifeddine, S. The heat treatment of Al-Si-Cu-Mg casting alloys. J. Mater. Process. Technol. 2010, 210, 1249-1259. [CrossRef]

23. Siddiqui, R.A.; Abdullah, H.A.; Al-Belushi, K.R. Influence of aging parameters on the mechanical properties of 6063 aluminium alloy. J. Mater. Process. Technol. 2000, 102, 234-240. [CrossRef] 
24. Milkereit, B.; Wanderka, N.; Schick, C.; Kessler, O. Continuous cooling precipitation diagrams of Al-Mg-Si alloys. Mater. Sci. Eng. A-Struct. Mater. Prop. Microstruct. Process. 2012, 550, 87-96. [CrossRef]

25. Yuksel, B. Effect of artificial aging on hardness and intergranular corrosion of $6063 \mathrm{Al}$ alloy. Pamukkale Univ. J. Eng. Sci. -Pamukkale Univ. Muhendis. Bilimleri Derg. 2017, 23, 395-398. [CrossRef]

26. Liu, S.H.; Wang, X.D.; Pan, Q.L.; Li, M.J.; Ye, J.; Li, K.; Peng, Z.W.; Sun, Y.Q. Investigation of microstructure evolution and quench sensitivity of Al-Mg-Si-Mn-Cr alloy during isothermal treatment. J. Alloy. Compd. 2020, 826, 11. [CrossRef]

27. Saito, T.; Marioara, C.D.; Royset, J.; Marthinsen, K.; Holmestad, R. The effects of quench rate and pre-deformation on precipitation hardening in Al-Mg-Si alloys with different $\mathrm{Cu}$ amounts. Mater. Sci. Eng. A-Struct. Mater. Prop. Microstruct. Process. 2014, 609, 72-79. [CrossRef]

28. Meyveci, A.; Karacan, I.; Caligulu, U.; Durmus, H. Pin-on-disc characterization of 2xxx and 6xxx aluminium alloys aged by precipitation age hardening. J. Alloy. Compd. 2010, 491, 278-283. [CrossRef]

29. Nandy, S.; Abu Bakkar, M.; Das, D. Influence of Ageing on Mechanical Properties of 6063 Al Alloy. Mater. Today-Proc. 2015, 2, 1234-1242. [CrossRef]

30. Zohrabyan, D.; Milkereit, B.; Kessler, O.; Schick, C. Precipitation enthalpy during cooling of aluminum alloys obtained from calorimetric reheating experiments. Thermochim. Acta 2012, 529, 51-58. [CrossRef]

31. Li, H.Y.; Zeng, C.T.; Han, M.S.; Liu, J.J.; Lu, X.C. Time-temperature-property curves for quench sensitivity of 6063 aluminum alloy. Trans. Nonferrous Met. Soc. China 2013, 23, 38-45. [CrossRef]

32. Cavazos, J.L.; Colas, R. Quench sensitivity of a heat treatable aluminum alloy. Mater. Sci. Eng. A-Struct. Mater. Prop. Microstruct. Process. 2003, 363, 171-178. [CrossRef]

33. Giersberg, L.; Milkereit, B.; Schick, C.; Kessler, O. In-situ isothermal calorimetric measurement of precipitation behaviour in Al-Mg-Si alloys. Mater. Sci. Forum 2014, 794-796, 939. [CrossRef]

34. Luoh, T.; Bow, J.S.; Peng, A.; Tsai, S.Y.; Tseng, M.R. Observation of recording marks in phase-change media using scanning electron microscopy channelling contrast image. Jpn. J. Appl. Phys. Part 1-Regul. Pap. Short Notes Rev. Pap. 1999, 38, 1698-1700. [CrossRef]

35. Frock, H.; Kappis, L.V.; Reich, M.; Kessler, O. A Phenomenological Mechanical Material Model for Precipitation Hardening Aluminium Alloys. Metals 2019, 9, 1165. [CrossRef]

36. Hamdi, I.; Boumerzoug, Z.; Chabane, F. Study of precipitation kinetics of an Al-Mg-Si alloy using differential scanning calorimetry. Acta Metall. Slovaca 2017, 23, 155-160. [CrossRef]

37. Vedani, M.; Angella, G.; Bassani, P.; Ripamonti, D.; Tuissi, A. DSC analysis of strengthening precipitates in ultrafine Al-Mg-Si alloys. J. Therm. Anal. Calorim. 2007, 87, 277-284. [CrossRef]

38. van de Langkruis, J.; Vossenberg, M.S.; Kool, W.H.; van der Zwaag, S. A study on the beta ' and beta " formation kinetics in AA6063 using differential scanning calorimetry. J. Mater. Eng. Perform. 2003, 12, 408-413. [CrossRef]

39. Ohmori, Y.; Doan, L.C.; Matsuura, Y.; Kobayashi, S.; Nakai, K. Morphology and crystallography of beta-Mg2Si precipitation in Al-Mg-Si alloys. Mater. Trans. 2001, 42, 2576-2583. [CrossRef]

40. Edwards, G.A.; Stiller, K.; Dunlop, G.L.; Couper, M.J. The precipitation sequence in Al-Mg-Si alloys. Acta Mater. 1998, 46, 3893-3904. [CrossRef]

41. Tsao, C.S.; Chen, C.Y.; Jeng, U.S.; Kuo, T.Y. Precipitation kinetics and transformation of metastable phases in Al-Mg-Si alloys. Acta Mater. 2006, 54, 4621-4631. [CrossRef]

42. Murayama, M.; Hono, K. Pre-precipitate clusters and precipitation processes in Al-Mg-Si alloys. Acta Mater. 1999, 47, 1537-1548. [CrossRef]

(C) 2020 by the authors. Licensee MDPI, Basel, Switzerland. This article is an open access article distributed under the terms and conditions of the Creative Commons Attribution (CC BY) license (http://creativecommons.org/licenses/by/4.0/). 